DOI https://doi.org/10.36059/978-966-397-108-7/127-143

\title{
REVOLUTION ON THE WESTERN BORDER OF THE RUSSIAN EMPIRE (IN WILLIAM HENRY CHAMBERLIN “THE RUSSIAN REVOLUTION. VOLS. 1-2")
}

\section{Anatolii Rusnachenko}

In this article I try to analyze the depiction of the revolutionary events in the national, Western parts of former Russian empire in the 2-volume scholarly study of one of the first historian of the Russian revolution William Chamberlin (1897-1969). He was American historian and journalist, author of some books on the Soviet Russia. From 1922 to 1934 he was correspondent of the newspapers The Christian Science Monitor (Boston), Manchester Guardian. I may admit that he thrown light mostly on Ukraine among other national revolutions. The term "national revolution", of course, was absent in the vocabulary of the author. His book received widespread acclaim in the West, but practically unknowing for the Ukrainian historians, readers, jet ideas of his research were used in the next scientific literature. He had communist sympathies until he lived in the Soviet Union. Then, gradually he turned anti-communist. He visited Ukraine and North Caucasus in 1932 and 1933 and witnessed Holodomor famines. The above-mentioned monograph was written when he was in the USSR and published first time in 1935. Returning to the USA in 1940, W.Chamberlin taught in some universities.

Concerning the saucers of his study of the revolutionary Ukraine, Baltic republics William Chamberlin used accessible to him well-known memoirs of V.A. Antonov-Ovsienko, E.Bosh, A.I. Denikin, monograph of N.R. Kakurin "Kak srajalas' revolucia", some other Soviet participants of revolution from Bolsheviks and the White sides, N.Popov including, Russian newspapers (Izvestia first of all), but he omitted resolutely all Ukrainians non-communist authors on the topic. The only 2 exceptions were 3 voluems of Volodymyr Vynnychenko" "Vidrodjennia natsii" and Arnold Margolin' "Ukraina i polityka Antanty". The main reasons of it seems to me simple- Chamberlin did not master Ukrainian, and other languages of the national minorities of the empire, was close to 
communist views at that time. Though, he visited Ukraine, have had some talks with different persons and used these tales and his own impressions into monograph. By the way he mentioned the archives of the Hetman regime with complaints of the local officials ${ }^{1}$, but he never cited it. Later, in 1944, he published other book on Ukrainian topic: The Ukraine: A Submerged Nation.

Author began his study with preparatory steps in the revolution: social forces in the Russian history, pioneers of the revolution. He shifted to the previous Russian revolution of 1905, impacts and results the WWI on the population. These factors eased by Bolsheviks to take power in the country, to reveal first steps of the new regime. And then the Civil war began. The historian used chronological approach in its narrative.

For W. Chamberlin the power of Central Rada in Kiev was shaky, and "was restricted to the Western part of Ukraina, where nationalist feeling was strongest, and where the industrial working class was relatively weak". ${ }^{2}$ But Rada became the master in Kyiv, disarming the Bolshevik forces in the city. Chamberlin overestimated Bolshevik influence in Kharkov and Donetsk in 1918. ${ }^{3}$ His definition of Galicians from Eastern Galicia as "very close to the Ukrainian in race and language" is strange. However, they are ethnographical parts of the united Ukrainian people.

Next pages of the chapter "Revolution in the country" devoted to events which later historians would name as "the first Russian-Ukrainian war in time of the Ukrainian revolution of the 1914-1923". 5

Concerning the troops of the Soviet Russia, its commander AntonovOvsienko (W.Ch. use the first half of family name of the former) established headquarters in Kharkov. His army was the partisan detachments of the il-disciplined force of 6-7 troops. However, author did not recognized Central Rada as such, he named it as "Ukrainian Rada", (or "Rada' simply) to which Radnarkom had sent its demands and proclaimed "if no satisfactory reply was received within 48 hours, Radnarkom will regard the Rada as in a condition of open war against the Soviet power in Russia and Ukraine." General Sekretariat-executive

\footnotetext{
${ }^{1}$ William Henri Chamberlin, The Russian Revolution. Vol. 1. 1917-1918. $2^{\text {nd }}$ ed. Crosset @ Danlap, New York, 1965. - Vol. 2. - P. 128.

2 Ibidem. - Vol. 1. - P. 349

${ }^{3}$ Ibidem.

${ }^{4}$ Ibidem. - Vol. 2. - 129.

${ }^{5}$ See my "Narysy novitnioi istorii Ukrainy". - Kyiv, 2014.
} 
body of Rada declared to Radnarkom, that "it was dishonest or contradictory for the Council of People's Commissars simultaneously to recognize Ukraina's right to self-determination and to impose its own form of political organization upon Ukraina. ${ }^{, 6}$

The reply of the Ukrainian General Secretariat did not satisfy the Russian Soviet demands. Ukrainian Soviet Government was organized on December 27 in Kharkov and the Council of People's Commissars in Moscow recognized it two day later. Rada possessed a considerable appeal the Ukrainian middle classes and to more educated peasants, but the social upheaval in revolution was stronger. For Chamberlin Kruti- is only railroad station where Rada drived back Muraviev, but was defeated after two-day battle. He mentioned also the mutiny of the pro-Soviet workers at the Arsenal. Author pictured the situation in conquered capital of Ukraine -Kyiv: shooting without trials and pillaging were common. ${ }^{7}$ Ukrainian historians added that to be killed was everybody who speak Ukrainian or was dressed nationally. Chamberlin had used term "excesses" on the brutality of invading troops, but in result of it nearly 2600 citizens were shooting. The Soviet Government ordered the requisition of all surplus food products under pretext of speculation.

Chamberlin wrote that it was no possibility to defend Kyiv by the Soviets, because they have small number of them, poorly armed and disciplined. So, in Kyiv was a panicky in the Soviets organizations. They ruled in capital three weeks only. Author did not mention the role of Ukrainian army in the liberation of Ukraine from Bolsheviks.

In the same chapter of the monograph Chamberlin wrote about attempts of introduction of the Soviet power on Kuban and Don, he referred about pro-Ukrainian Kuban Popular Rada in next volume.

Ukrainian question reappeared in the chapter "Brest-Litovsk: the struggle for peace". W. Chamberlin indicated that representatives of the Central Rada were participants in the negotiations. German and Austrian diplomats now rejected the right of Trotzky to speak for all former Russian lands. Germans and Austrians were ready for separate peace with Ukraine. Historian admitted that the Ukrainian delegates put forward some territorial demands: Austro-Hungary should cede to Ukraine East Galicia and Bukovina, because Ukrainian population was dominating

\footnotetext{
${ }^{6}$ William Henri Chamberlin, The Russian Revolution. Vol. 1. - P. 374.

${ }^{7}$ Ibidem. Pp. 375.
} 
here, Kholm gubernia, now in Poland should be in Ukraine too. Germans and Austrians refused to any cession of the Austrian territory, but trying to weak of Poland, compromised for Kholm. In Austria Crown Land was to be created out of East Galicia and Bukovina. ${ }^{8}$

The problems of the Baltic nations were mentioned at the BrestLitovks negotiation in this chapter too, but shortly. Author wrote about speech of general Hoffman, who referred 1918, January 12 to the acts of Curland Popular Assembly, the Lithuanian landrat, the municipal administration of Riga and others which "repudiated all connection with Russia and appeared to Germany for defense". But these bodies could not be regarded as nationally representative, Chamberlin remarked. They were delegates elected as a rule by "the German racial minority in the Baltic States". I may point out that by the time of these peace talks the independence of Estonia and Latvia yet was not proclaimed.

With resume of the Brest-Litovsk peace negotiations Soviet delegation included two representatives of the Soviet Ukraine- Medvedev and Shakhrai. The government of the Ukrainian People's Republic (UPR) was in danger, but Central Powers on February 1 announced the recognition of the UPR. They were sure in their military potential to overthrow the Soviets in Ukraine. ${ }^{10}$ Trotzky sarcasm about "non-existence of Ukrainian Republic" passed without visible result. The peace treaty of Ukraine with Central Powers was signed on February 9. It meant the German and Austrian assistance in the struggle with Bolshevik Russia in exchange for foods from Ukraine. ${ }^{11}$

Trotzky refused to sign peace agreement with Central Powers and left Brest-Litovsk February 10. Three days later Germans after a council of chief military and civilian authorities decided "to strike a brief hard blow... by advancing the line of occupation to the eastern boundaries of Latvia and Estonia"12. German advance to East began in February 18.

Vladimir Lenin position at the meeting of the Central Committee of the Bolshevik party was clear: if Estonia, Latvia and Finland were giving up the Revolution was still not lost. We may remember that Bolsheviks had great successes in these provinces, but Lenin wanted to preserve

\footnotetext{
${ }^{8}$ William Henri Chamberlin, The Russian Revolution. Vol. 1. - P. 393.

${ }^{9}$ Ibidem. - P. 395.

${ }^{10}$ Ibidem. - P. 399.

${ }^{11}$ Ibidem. - P. 400.

${ }^{12}$ Ibidem. - P. 401.
} 
revolution in real Russia. For the resuming of peace talks Germans demanded: "evacuation of Latvia and Estonia by Russian troops and Red Guards; the immediate conclusion of peace between Russia and Ukrainian people's Republic and the withdrawal of Russian troops and Red Guards from Ukraina and Finland". Chamberlin wrote that meant a protectorate over Ukraine and Finland and annexation of Baltic Provinces. ${ }^{13}$

In passing, author recalled separate regions in Ukraine that created its own Soviet Governments, but did not name them, he did not write about reasons which brought these governments to existence.

William Chamberlin scrutinize the regime Pavlo Skoropadsky in Ukraine after the coup d' etat in April 1918. His main argument of its necessity for the Germans was that they found out the Rada not sufficiently subservient. Hetman Pavlo Skoropadsky completely dependent upon support of German army and was popular with landlords and the well-to-do classes of the towns. His conservative regime was greeted well by the numerous refugees from Soviet Russia also. ${ }^{14}$ In the next volume Chamberlin took more attention to general Skoropadsky as a leader of the state and the state which he represented. For historian Hetman was no in any sense a nationalist, but he imparted of his regime a skin-deep Ukrainian coloring. For Ukrainian nationalists (and for Chamberlin himself) Skoropadsky was the puppet ruler who has been installed by Germans. He was unpopular, because of his social policy. ${ }^{15} \mathrm{In}$ result of it were general strike of the Ukrainian railroad workers, terrorism and sabotages in the towns. In countryside there "was an intermittent guerilla war", in form of local uprisings, or more often in form in killing, robberies, burning of manour-houses. ${ }^{16}$

Historian try to explain the reasons of the "peasant guerilla bands" that cut off small part of foreign soldiers, raiding landlords' estates and killing their owners. First explanation: Skoropadsky endeavored to return land seized by peasant to its former owner; second- too much foodstuffs was delivered from Ukraine to Germany according to peace agreement between both sides. But Chamberlin said nothing about proposed land reform of Hetman P.Skoropadsky according to what all the landlords' lands must be redeemed by the state, every holder of the land may own no more than

\footnotetext{
${ }^{13}$ William Henri Chamberlin, The Russian Revolution. Vol. 1. - P. 403.

${ }^{14}$ Ibidem. - P. 409.

${ }^{15}$ Ibidem. - Vol. 2. - P. 125.

${ }^{16}$ Ibidem. - P. 126.
} 
25 ha. ${ }^{17}$ He made mistake, writing about lively communications of the Ukrainian communists, who took refuge in Moscow, with insurgents in border zone of Ukraine. Communists attempted to organize one big peasant uprising in Chernigov gubernia (Mykola Kropyvianskiy-A.R.).

Chamberlin was well informed about running of the first congress of the Communist party of Ukraine in July of 1918, division between delegates on a left-wing group headed by Bubnov and Pyatakov and moderate group headed by Kviring. When regime of occupation was crumbling, the Central Committee of the Russian Social-Democratic Worker's party decided to organize the government for the Soviet Ukraine. ${ }^{18}$ Was or not the German presence in Ukraine an occupation in 1918 is an item for discussions of the professional historians now. ${ }^{19}$ The Hetman tried to save its power after the beginning of the revolution in Germany, dropped with idea of "independent Ukraine".

Historian estimated Directory as a feeble improvisation of a government. For him the army of restored UPR was "a disorderly horde, definitely inferior to the newly organized Red Army in discipline and in staffing with trained officers". But he wrote that many of these troops of Directory were close to Bolshevism, and in the same time wrote about conservative military practice of some of the atamans. ${ }^{20} \mathrm{He}$ explained sympathy of the peasants to Bolshevik in the days of Red Army offensive on Ukraine by such reason: they knew the Bolsheviks only as the people who gave them the land, not as those who should confiscate their grain. We may admit that Ukrainian population had small information on Bolsheviks aspiration during their first occupation of Ukraine.

Detailed information author presented on Finland. It was drawn into the German influence. In Finnish Diet was created non-Socialist majority, and Soviet Russia recognized Finnish independence on December 31 of 1917. But January 26 of the next year the government was overthrown and Red regime established in the south and southwest. Civil war between the Reds and the Whites continued some weeks. Concluding the peace with Germany, the "White" Finnish government received military support

\footnotetext{
${ }^{17}$ Doroshenko Dmytro. Istoria Ukrainy. - Kyiv, 2002. - T. 2. - S.s. 199-200. The former owner of the land should left with building and 25 ha too.

${ }^{18}$ Ibidem. - P. 128.

19 See: Dornik Wolfram, Kasianov Georgii, Leeb Peter, Liadinger Gannes, Miller Alexiy, Musial Bohdan, Rasevych Vasyl'. Ukraina: mij samovyznachenniam I okkupacieyu: 1917-1921 roky. - K., 2015 (transl. from German).

${ }^{20}$ William Chamberlin. The Russian Revolution. Vol.1. 1917-1918. $2^{\text {nd }}$ ed. - Vol. 2. - P. 130.
} 
of the former: expeditionary force under general von der Goltz. This corps determined the victory of the "Whites" in the war. Russian troops, that supported "Finnish Socialist Republic" were withdrawn from Finland according to the Brest-Litovsk treaty.

W.Chamberlin made very interesting note concerning the German possibility of preventing of Bolshevism in Russia, if she would not lost the war:

"For the subsequent Allied intervention in Russia, feeble and halfhearted, intermittent and constantly thwarted by the cross-purposes and conflict interests of its initiators, was a less serious threat to the Soviet existence than intervention of the type which Ludendorff and Hoffmann would probably have sponsored, if their system had survived the shock of military defeat.",21

The new revolutionary Red offensive toward the West (and South) was set after Germany's defeat in WWI. Chamberlin thought that the Bolsheviks in their race with the Allies for establishment of their supremacy had some advantages. They had available troops for it and were better acquainted with local situation than were Allies powers. ${ }^{22}$ In its drive for Baltic provinces Bolsheviks had armies recruited from the natives Lithuanians, Latvians and Estonians. The Latvian fought in 9 regiments. So, in December-January of 1918-19 Red army was successful in establishment of the Soviet republics on the Baltic. It worth to underline that all these new Soviet republics imaged firstly themselves autonomous parts of the Soviet Russian Federation only, but not as independent states. Only under strong recommendation from V. Lenin their leaderships agreed to be "independent". By then, revolutionary spirit of these native Red soldiers evaporated mainly.

By February 1919 Estonian territory was cleared from invaders. Northwestern White Army used Estonia as a base for attacks on Soviet territory. In Latvia, the Reds were masters of nearly all territory by the end of March. Here was formed Iron Division of Count von der Goltz which was composed from the volunteers of the German occupation army and the recruits from the local German aristocracy. The division captured Riga by end of the May. White terror changed Red one. Author wrote

\footnotetext{
${ }^{21}$ William Chamberlin. The Russian Revolution. Vol.1. 1917-1918. $2^{\text {nd }}$ ed. - Vol. 1. - P. 412.

${ }^{22}$ Ibidem. - Vol. 2. - P. 206.
} 
about "nationalistic spirit of the Baltic peoples, desired to severe all connection with Russia, were abandoned". 23

It looks, as author of the 2nd volume knew nothing about national revolution in Belorussia. She was mentioned as the place of Soviet-Polish armed conflict only.

Chamberlin stated, that the second occupation of Ukraine by the Soviets was attributable to political and social rather to military causes. It is difficult not agree with this statement. The Soviets used the fall of Hetman P.Skoropadsky and disappearance of the German and Austrian forces of occupation, and run on Ukraine. Author was absolutely true when writing that "Ukrainian peasants did not know from personal experience of some features of Communist policy as institution of Committees of the Poor, "the requisition at the point of the bayonet". For peasants, Bolsheviks were people who told them to seize the land, property of the rich. ${ }^{24}$

I do not support Chamberlin statement, that Directory which came to power in result of overthrowing of Hetman was somewhat discredited because it was successor of the Central Rada which has invited Germans. Certainly, Volodymyr Vynnychenko, one of members of Directory, a writer, had communist inclinations. Worker's Congress, from which the propertied classes were expelled, as from the Soviets, was convoked to legitimize the Directory of Ukrainian People' Republic. But Congress represented mostly to the peasants and to the village teachers, doctors, agronomists, cooperative store employees, and city workers too, as pointed out Chambelin. It is necessary remember that almost all represents of bourgeoisie, landlord in Ukraine as in Baltic provinces were not natives but Russians, Poles, Jews, Germans and other non-Ukrainians.

Why the Directory revealed unable to stand firmly in Ukraine? Chamberlin try to answer on the question, he put forward some explanations: the actions of the "atamans" - military leaders of Ukrainian troops did not agree with the words of the civilian leaders; small pogroms of Jews alienated numerous and active Jewish socialists groups in the cities; rumors circulated by the Communists that Directory had concluded a secret treaty with the Allied military authorities in Odessa. Additional factor of weakness of the Directory were their military forces, consisting largely of peasant levies, which obeyed only their atamans with low

\footnotetext{
${ }^{23}$ Ibidem. - P. 208.

${ }^{24}$ William Chamberlin. The Russian Revolution. Vol.1. 1917-1918. $2^{\text {nd }}$ ed. - Vol. 2. - P. 212.
} 
discipline, lack of officers and ammunitions. Only Galicians have maintained good discipline, Chamberlin admitted. ${ }^{25}$ I may add to these points yet some of former insurgent detachments turn to the Soviet side in decisive moment, for some time- Grigoriev, Zelenyi. The Soviet leaders determinately strived restore the Soviet power in Ukraine and reunite it with the Soviet Russia, as the first step to the World revolution (L.Kamenev), many Russian political statesmen, leading figures in the Communist party simply did not see Ukraine, but "south of Russia". 26 They need Ukrainian grain, coal, metal and so on, but not the independent Ukraine. So, they immediately moved against army of the UPR.

The interventionist forces of the Allies were unable to undertake large-scale offensive operations on the Ukrainian south. Ataman Grigoriev dislodged French and Greek troops, occupying Kherson, Mykolaiv (March 10,12 of 1919), French troops evacuated Odessa in early April, Soviet troops occupied Crimean peninsula.

Ukrainian forces after long retreat found themselves at the small territory of the west border of republic in April 1919. Soviets tried to pass through Ukraine to Hungary after establishing there a Soviet Republic. In January 1919 the mutiny against Romanian rule outbreak in Bessarabia. It was suppressed, but fugitives crossed the border and had taken refuge in the Soviet territory.

Uprising of the troops of ataman Grigoriev and advance of Anton Denikin's troops prevented Soviet raid to Hungary and spread of the revolution to Europe. Chamberlin underlined that Grigoriev's uprising was biggest, but not the only. Many anti-Soviet bands composed mostly from peasants appeared in Ukraine and attacked Soviet administrations, Red patrols, wrecking trains. On April 10 these guerillas detachments (Zelenyi and Struk-A.R.) dashed into Kyiv. ${ }^{27}$

W.Chamberlin especially elucidated the mutiny of ataman Grigoriev, its reasons and results. He cited V.Antonov-Ovsienko memoires about causes of the revolt, and among them:

"1.Local government authority is completely unorganized and to a certain degree is imposed on the majority of the population.

\footnotetext{
${ }^{25}$ Ibidem. - P. 213.

${ }^{26}$ Vtoroi s'ezd Kommunisteecheskoi partii (bolshevikov) Ukrainy 17-22 oktiabria 1918 g. Protokoly. Kyiv, 1991. - S. 91, 115. Nestor Makhno.Vospominania. -Kharkov, 1999. - Kn. 2. - S. 97. 121-122, $134,135$.

${ }^{27}$ William Henri Chamberlin, “The Russian revolution”. - Vol. 2. - P. 215.
} 
2. Food officials who are not appointed from among local people acting without knowledge of the situation, have aroused the village very much against the central Soviet Government.

3. The Chekas, which become state within the state, are almost universally hated and almost everywhere create complication for the Soviet regime.

...5. The population after the arrival of the Soviet regime, received almost nothing, except an increase in the cost of and a lack of products.

...9. Tactless attitude of the central authorities toward the national feeling of Ukraine..., 28

So, Chamberlin concluded that Ukrainian village experienced the same disillusionment with Soviet agrarian policy that the Russian village experienced a year early. Grigoriev troops were peasantry mostly. To the last moment Antonov-Ovsienko hoped that it would be possible to use these troops against Romania. But on May 7 of 1919, Nykyfir Grigoriev revolted, seizing the town of Elizavetgrad. He issued a manifesto (Univesal, according to Cossack traditions-A.R.). Grigoriev called on the peasants to mach on Kyiv and Kharkov with arms, or pitchforks and to overthrow the government of the "adventurer Rakovsky". The latter was a chair of the government of the Ukrainian Socialist Soviet Republic. For Ukrainian reader everything was understandable: pitchfork- was the peasant weapon in time of the last big peasant uprising named Koliivschyna (XVIII cent.), Kyiv was an ancient capital of Ukraine, Kharkov- capital of the communist Ukrainian SSR. It looks as the Chamberlin did not know these details. But historian set forth proposals of the Univesal which show its national character: to call a freely elected Congress of Soviets, where $80 \%$ of the place would be for Ukrainians, $5 \%$ - for Jews, the rest- for other nationalities. ${ }^{29}$ Chamberlin did not comment these proposals, though they speak for themselves, about real character of the Soviet power in Ukraine. He wrote that Grigoriev was confident he can smash the Communist power in Ukraine and acted accordingly, sent small detachments across Ukraine. His soldiers made pogroms too. So, the Soviet proclaimed Grigoriev outlaw and forced out off main centers and railroads. In result of the mutiny which Red army suppressed later, the rear of this army against Denikin was destroyed, the number of the Soviet forces at the front was reduced. Ukrainian peasants

\footnotetext{
${ }^{28}$ William Henri Chamberlin, “ The Russian revolution”. - Vol. 2. - P. 216.

${ }^{29}$ Ibidem. - P. 218.
} 
as recruits, Chamberlin noted, revealed unreliable against insurgents. In these revolts author noticed absolute absence of monarchist appeals or aspirations to restore the previous order. ${ }^{30}$

Summing up the mass protests in Ukraine (partly-Russia) Chamberlin make interesting conclusions that these mutinies, uprisings "quite unconsciously, combating the spread of Communism in Europe much more effectively than the war-weary Allied troops".

Special chapter (vol.2.) historian spared to the only Ukrainian problems, or more accurately, to the some events in Ukraine. He named it: "Ukraina, whirlpool of peasant anarchism". In the chapter author tried to understand spirit and motives of majority of Ukrainian population. Firstly he tried to conceive the logic and reasons of acting peasant "guerrilla bands". W.Chamberlin stated that peasants' desires were equally far from communism and the restoration of the old imperial regime. They were determined to keep the seized land, resentful of demands for food and army recruits of Reds and Whites, hated the state farms and communes introducing by Bolsheviks. ${ }^{31}$ Former and latter could not give the peasants any manufactured goods in time of wars, but big inflation, rise of prices only.

Chamberlin explained far more conscious of their own interest in Ukrainian peasantry than in Russia by next factors. On the national character strongly influenced Zaporozhian Cossak Republic, serfdom had not such a long tradition in Ukraine as in Russia. Even standard of living in Ukraine was higher than in Northern and Central Russia. Here was a larger class of peasants with a sense of property.

Historian noticed direct link between this "peasant anarchism" and national composition of population in the villages, the cities and towns of Ukraine. In the northern, western provinces villages were almost Ukrainian, but in the towns Russians and Jews were majority. Communist Party of Ukraine was recruited its members from towns. That is why the catchwords "All Jews are Communists" and "Kill the Jews and Communists" were popular of the time. National feeling strengthened the antipathy of Ukrainians to regime of Denikin who could not recognize neither Ukrainian language, nor culture, Ukraine did not exist simply for him, (as for many Russian communists too- $A . R$.). ${ }^{32}$ Chamberlin wrote that many, swift changes of governments in these years explained also this

\footnotetext{
${ }^{30}$ William Henri Chamberlin, “ The Russian revolution”. - Vol. 2. - P. 219.

${ }^{31}$ Ibidem. - P. 221.

${ }^{32}$ Ibidem. - P. 223.
} 
"anarchism". He did not know anybody of the Ukrainian military persons of the time, but Petlura only.

For him, Symon Petlura was unable to make military victory against Reds or Whites. So, "consequently the Ukrainian nationalistic movement took the form of guerilla bands" activity headed by a host of atamans. Chamberlin even did not try to find out the real good excuses of the problems of Dievoi armii (Acting army) of the UPR. He did not notice that Ukrainians were forced to wage war with Red and White Russia, Poland, Romania, Hungary, Allies and Central Powers, partly against some of them simultaneously. But he acknowledged that these Petlurists distributed in small bands might deliver far more damages to their enemies than the same number of regular troops. ${ }^{33}$

W. Chamberlin analyzed appeals, manifestos of some atamans: Volynetz, Zeleny, Angel, Bozhko, Struck. In the words of the historian, the peasants were called on to rise against the requisitions, cruelty of the military detachments which carry them out, under slogans: "Down with the communists, Chekas, commissar-tyrants" also. He noticed that these insurgents might support and supported idea of Ukrainian independent Soviet republic. The meaning of the last expression maybe was understandable for contemporaries and author himself, but needs clear explanation for future readers. He continued, that such appeals to peasants many times found responses even in "the Ukrainian Red troops". Again, historian used last term and "Ukrainian Red Army" but never tried to find out of their meanings.

Chamberlin explained reasons for pogroms in Ukraine by the disappearance of any effective authority in the country, brutality of long war and civil strife. The revolution gave right to any kind of pillage or violence directed against "boorzhui". Pogroms against Jews, he wrote, was rooted in Ukrainian and the Russian imperial history. In time of revolution the pogroms against town middle class- traders became antiJewish, because the latter consisted majority of this class. ${ }^{34}$

A very important cause for pogroms at this stage of revolutionary war was the identification in the popular mind of the Soviet regime, the Communists with Jews. Chamberlin noted, that Jews played prominent role both in the Communist party and in the Russian revolutionary movement, it is obvious and understandable. A considerable number of

\footnotetext{
${ }^{33}$ William Henri Chamberlin, “ The Russian revolution”. - Vol. 2. - P. 224.

${ }^{34}$ Ibidem. - P. 226.
} 
them were the leading figures in the Communist Party and in the Soviet government. Many younger Jews were in the Soviet administration, it had fatal consequences for others Jews when the towns left the Red troops.

W.Chamberlin accused the Ukrainian troops as the main perpetrators of pogroms, the various atamans and the Denikin forces, some units of "Ukrainian Red Army" too. The Soviets strictly forbade the pogroms, expression of anti-Semitism in literature. Makhno insurgents did not make pogroms also. Historian admitted that V.Vynnychenko was not antiSemite, and Petlura regime officially was not anti-Semitic too. Ukrainian government organized a Ministry of Jewish Affaires headed by Jew, Petlura issued orders to forbade any pogrom agitation. ${ }^{35}$ The problem was to control fulfillment that order in troops, with individual atamans.

The pogroms accomplished troops of the Whites too. Denikin himself denied that he desired or encouraged pogroms by his army. Chamberlin cited a result of investigation of pogroms carried out by the Whites and its traits: they were purely military by character, with the mass violation of the women, the special cruelty and tortures, and the rooting out of the whole communities. ${ }^{36}$

Bands of red partisans often made atrocities against propertied classes also. The Chekas murdered thousands of victims too.

Among the leaders of revolutionary times W.Chamberlin distinguished of Nestor Makhno, presented his biography, first steps as an anarchist and his close cooperation with Bolsheviks in the beginning of its leadership of small partisan army and some months later in the Ukrainian South. Author stressed, that Makhno was a theoretical anarchist, was not an Ukrainian nationalist. Jewish anarchists were prominent in his entourage, including the head of its private cheka. Often author named Makhno as an anarchist chieftain. ${ }^{37}$

Chamberlin wrote that difficulties between Makhno and the Red Command soon began to develop. These difficulties, author noted, were rooted in different attitude to the ideological and political problems of future society and power. At the congresses of insurgent peasants the critic of the Soviet power was free and outspoken. Makhno refused to cooperate with Grigoriev, but emphasized that he fight for freedom of the

${ }^{35}$ William Henri Chamberlin, “ The Russian revolution”. - Vol. 2. - P. 229. See also: Volodymyr Sergiichuk. Pogromy v Ukraini 191401920. - K., 1998. - S.s. 198, 199, 245, 250, 265-268, 271, 300, 304-306 and so on.

${ }^{36}$ William Henri Chamberlin, “ The Russian revolution”. - Vol. 2. - P. 231.

${ }^{37}$ Ibidem. - P. 233. 
people but not for the government power. His lieutenant killed Grigoriev, some his closest commanders.

The most extreme enemy of the Makhno movement was Lev Trotzky. So, the former was dismissed from his post as a Commander of his army. For Chamberlin, during of the summer of 1919 Makhno led the life of insurgent ataman. By autumn of 1919 Makhno movement reached its peak. ${ }^{38}$ This movement played most decisive role in undermining of Denikin rear. Makhno troops had taken important ports Berdiansk, Mariupol, towns Alexandrovsk, Nikopol, seized important railroad junctions, Lozovata and Sinelnikovo. By this last action the insurgent troops cut off the Whites from their bases of supply. Late in October 1919 Makhno took Ekaterinoslav, the most industrial center of the region. It is necessary to add that Makhno never stopped for long time in the towns, because their inhabitants were alien for him. And any power -the Soviet or former imperial for his soldiers was evil by their definition. Chamberlin stressed:

"Profound hatred and distrust of the state, as an organ of power and for political parties characterized all Makhno's of public proclamations."39

In these proclamations, Chamberlin admitted, was clear influence of the anarchist "Nabat" group. These persons tried and with success (to some degree as for me) to transform of this peasant uprising into the anarchist revolutionary movement.

Author depicted systems of Makhno army, its election of commanders, its discipline in the conquered towns. Chamberlin left for us some individual traits of the peasant leader. He stressed of Makhno' rare daring, shrewdness and resourcefulness. Makhno was a master of the tricks which were effective in time of guerilla war and turmoil.

Makhno troops retreated after big victories in autumn of 1919 under pressure of retreating Denikin. The big enemy of all armies waged this war- typhus thinned Makhno's forces too. When Red Army returned into Ukraine Makhno waged war against Soviet administration, especially food collectors. He refused to go with Red Army to the Polish front and was declared outlaw. ${ }^{40}$ Such declaration took place second time, with Trotzky' initiative. Makhno moved about Ukraine, making long raids during 1920. Chamberlin wrote, that "Makhno was popular with a

\footnotetext{
${ }^{38}$ William Henri Chamberlin, “ The Russian revolution”. - Vol. 2. - P. 234.

${ }^{39}$ Ibidem. -P. 236.

${ }^{40}$ Ibidem. - P. 237.
} 
considerable part of the peasants; and their sympathy probably explains his "continual success in evading pursuit".

P. Wrangel' advance in September 1920 determined position of Makhno army as an ally of the Soviet Southern front by signing of a military-political agreement. It provided participation of Makhno troops in war against Wrangel, though as independent and with its internal organization of military units. These troops stormed and passed Sivash bay. After the victory, Communists found pretext alleging that Makhno had broken agreement. November 6, 1920 Makhno and its army were proclaimed as the enemy of revolution. ${ }^{41}$ So, the Red troops launched an offensive against Makhno partisans in its center Gulai Pole and in Crimea. Many those who were battled against Whites in Crimea suffered heavy losses from the Reds, including commander of the unit Simon Karetnik (Karetnikov). Makhno escaped himself, but three members of his delegation were arrested in Kharkov and shot by Cheka later. Nearly half a year Makhno raided about Ukraine and even some parts of Russia, but did not find previous support. Soviet regime consolidated and might liquidate even big peasant armies.

Makhno finished its struggle in August of 1921. With small detachment he crossed the Dniester River into Rumania.

Chamberlin estimated his activity in such words:

"He carried out in practice, in primitive, effective fashion, what the Socialist Revolutionary intellectuals had advocated in theory; he had fought on two fronts, against Red and Whites alike, in the name of what he and the peasants who followed him believed was freedom." 42

Ukraine appeared on the pages of the $2^{\text {nd }}$ volume of the Chamberlin work in the next chapter. Author wrote here on the fate of the Armed Forces of South Russia and his head general Anton Denikin. In this chapter Ukraine is a field of struggle between the Whites and the Reds rather than object of sovereign activity. So, the former entered Kharkov on June 25 of 1919. Big part of Eastern Ukraine was occupied by the Whites. Shkuro troops had overrun Gulai Pole, took Ekaterynoslav. But the innumerable partisan groups (bands) began its actions against the Whites. ${ }^{43}$ Combined attack from land and sea coordinated from the officer's underground organization in Odessa placed city to the hands of

${ }^{41}$ Savchenko A.A. Izmena "bat'ki” Makhno I "jeleznai metla" L.D.Trotzky // Istoria SSSR, 1990. № 2. - S. 87 .

${ }^{42}$ William H. Chemberlin, The Russian Revolution. - Vol. 2. - P. 239.

${ }^{43}$ Ibidem. - P. 245. 
the Whites in late August, while Kherson and Nikolaev were taking some early. Kyiv was taken by them on August $31 .^{44}$ It is necessary correct the author which wrote that Whites were pushing out the Petlurist troops which had entered Kyiv the day before. The city was taken by military formations of the Ukrainian Galycian Army under command of general Antin Kravs after the brutal combats with Reds. But approaching Whites run in the liberated city too, from the left bank of the Dnieper. Kravs, having an order from Petlura do not fight against Denikin troops, did not overcome the situation and Ukrainian troops were forced to withdraw to demarcation line.

In the Denikin rear peasants were certainly dissatisfied with the Whites and many of the workers were sympathetic with Bolshevism, Chamberlin continued. For him, peak of Denikin's success occurred on October 12, when the Whites occupied Chernigov. In the same time southern Ukraine was falling into the partisans bands of Makhno which led fierce insurrection into the Whites' rear. So, a part of troops were diverted from front to combat Makhno. ${ }^{45}$ Denikin was defeated, because he was nationalist, devoted to idea "Russia shall be great, united, undivided". Even more, stated Chamberlin:

"The practice of Denikin's military officers and civil administrators was almost invariably much more restorationist than the vague generalized official declarations about aims of the movement." 46

Denikin army took advantage on the territory where Ukrainian peasantry felt of the bitter resentment against the Bolsheviks. To win in native Russia, Chamberlin continued, was only possible if the Ukrainian peasants could be convinced that Denikin system was more compatible with their interests that was the Soviet regime. This political and social test Denikin failed to pass. ${ }^{47}$ Though, some times, in Odessa and Kyiv workers greeted him with the traditional Russian 'bread and salt". But generally, workers remained hostile to his affairs, even more- the Ukrainian peasants.

But the main mistake of Denikin, Chamberlin admitted, was his nationality policy. Under his control was the predominantly non-Russian population and victory depended on the ability to unite these nationalities around its slogans. This revealed impossible: general was unfitted to this "by

\footnotetext{
${ }^{44}$ William H. Chemberlin, The Russian Revolution. - P. 246.

45 Sbidem. - P. 249.

${ }^{46}$ Ibidem. - P. 251.

${ }^{47}$ Ibidem. - P. 255.
} 
his blunt, direct, soldiery mentality and his strong Russian nationalism". Especially in Ukraine, Chamberlin write, everything in Ukrainian language was forbidden. For Denikin and his lieutenants Ukraine did not exist, only "Little Russia". With Petlura troops Denikin waged war, thereby diverting still more troops from its general direction toward Moscow. ${ }^{48}$ Denikin ignored the pretension on autonomy of the Kuban Cossack Rada too. His administration in Ukraine was weak and could be supported the landlords, former pre-War Russian ruling class. The similar situation was in occupied by its troops non-Ukrainian regions too.

\section{CONCLUSIONS}

Writing the history of Russian revolution on the Western border of the former Romanov empire W.Chamberlin used mainly, and in some chapters- nearly exclusively papers, books published by Soviet side only. But it not prevented this monograph from trustful explanations of the revolutionary events in its some general traits. His main object of research is Great Russia, all other events are depicted as a secondary. Revolution in Ukraine is a good exception. He tried to speak about it honestly, but big concentration on the Russian reality first of all, absence of knowledge of the Ukrainian language and literature limited his narrative. His conceiving of the Western/Eastern Ukraine was erroneously, the events in the true Western Ukraine are absent in the research. His attention was more to N. Makhno than to other leading figures of Ukrainian revolution. The letter definition did not exist in his text. Chamberlin did not make any remarks about the Russian nationalism of the Soviet leaders and creation the Soviet empire instead of the Romanov' one in his monograph. Contemporary Ukrainian historians may to accept the Chamberlin estimation of the revolution in the Western part of empire with certain limitations only.

Information about author: Rusnachenko A.

Professor of the Department of Philosophy and History of the Taurida National University

${ }^{48}$ William H. Chemberlin, The Russian Revolution. - P. 259. 